\title{
New data on the distribution and size composition of the North Pacific spiny dogfish Squalus suckleyi (Girard, 1854)
}

\author{
ALEXEI M. ORLOV ${ }^{1}$, VADIM F. SAVINYKH ${ }^{2}$, EUGENY F. KULISH ${ }^{1}$ \\ and DMITRY V. PELENEV ${ }^{1}$ \\ ${ }^{1}$ Department of International Fisheries Cooperation, Russian Federal Research Institute of Fisheries and Oceanography \\ (VNIRO), Moscow, Russia. E-mail: orlov@ vniro.ru \\ ${ }^{2}$ Pacific Fisheries Research Center (TINRO-Center), Vladivostok, Russia
}

SUMMARY: The results of long-term research on the spatial and vertical distribution of the North Pacific spiny dogfish Squalus suckleyi in the North Pacific Ocean and its size composition are presented. In total, data from 7059 catches of this species were analyzed ( 3178 with associated capture depth). The description of size composition is based on measurements of 413 specimens caught by driftnets, 328 by pelagic trawls and 722 by bottom trawls. This species was found to be most widely distributed in the North Pacific in the summer and autumn months during feeding migrations. Seasonal and long-term changes in the spatial distribution were observed. A wide distribution of S. suckleyi in the Bering Sea was recorded after the year 2000, which is likely associated with recent climate change. Occurrence of the species in the water column and near the bottom differed considerably. In the water column, the maximum number of captures was observed within the upper $25 \mathrm{~m}$ layer (about 90\%). Near the bottom, this species was most abundant at depths less than $50 \mathrm{~m}$ (over $45 \%$ ) and within a depth range of 101-200 m (about 50\%). The catch of $S$. suckleyi during the daytime was considerably larger than in the night, possibly due to vertical diurnal migrations. This species was found at water temperatures ranging from 0 to $12.7^{\circ} \mathrm{C}$, and maximum catches were observed at temperatures over $8^{\circ} \mathrm{C}$. Size compositions of bottom and pelagic trawl catches were similar (mean length 69.1 and $68.6 \mathrm{~cm}$ respectively) while driftnet catches were composed of larger specimens (mean length $75.3 \mathrm{~cm})$.

Keywords: North Pacific spiny dogfish, Squalus suckleyi, distribution, size composition, North Pacific Ocean.

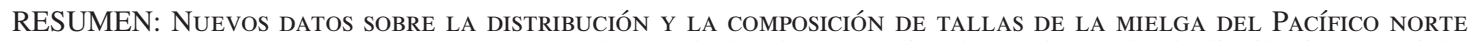
SQUALUS SUCKLEYI (GIRARD, I 854). - Se presentan los resultados de un estudio a largo plazo sobre la distribución espacial y vertical y la composición de tallas de la mielga del Pacífico norte, Squalus suckleyi. Se analizó la captura de 7059 ejemplares de esta especie (de los que 3178 disponían de datos de profundidad de captura). La composición de tallas se basó en las medidas de 413 ejemplares capturados mediante redes de deriva, 328 por arrastres pelágicos y 722 por arrastres de fondo. La especie se distribuye más ampliamente en el Pacífico norte durante los meses de verano y otoño, asociada a migraciones alimentarias. Se observaron cambios estacionales y a largo plazo en la distribución espacial. En el Mar de Bering se registró una amplia distribución de S. suckleyi después de 2000, probablemente asociada a cambios climáticos recientes. La presencia de la especie en la columna de agua y cerca del fondo difiere notablemente. En la columna, el número máximo de capturas (cerca del $90 \%$ ) se observó en los primeros $25 \mathrm{~m}$ de profundidad. Cerca del fondo, la especie fue más abundante a profundidades menores de $50 \mathrm{~m}$ (más del 45\%) y en el rango 101-200 m (cerca del 50\%). Las capturas de S. suckleyi durante el día fueron considerablemente mayores que durante la noche, posiblememente debido a migraciones verticales diurnas. La especie se registró en un rango de temperaturas de 0 a $12.7^{\circ} \mathrm{C}$, y las capturas máximas se dieron por encima de $8^{\circ} \mathrm{C}$. La composición de tallas de los arrastres pelágicos y de fondo fue similar (talla media de 69.1 y $68.6 \mathrm{~cm}$, respectivamente), mientras que las capturas mediante redes de deriva presentaron ejemplares mayores (talla media: $75.3 \mathrm{~cm}$ ).

Palabras clave: mielga del Pacífico norte, Squalus suckleyi, distribución, composición de tallas, Océano Pacífico norte. 


\section{INTRODUCTION}

The taxonomic status of Squalus suckleyi has undergone some changes. After the original description by Girard (1854), the name S. suckleyi remained in the scientific literature during the next hundred years (Jordan and Evermann 1896, Garman 1913, Starks 1917, Walford 1935, Schultz 1936, Clemens and Wilby 1946). The taxon was then considered as a junior synonym (Bigelow and Schroeder 1948, 1957, Jones and Geen 1976) or subspecies (Lindberg and Legeza 1956, 1959) of Squalus acanthias. However, recently the development of new techniques involving DNA analysis has allowed researchers (Ward et al. 2007, Verissimo et al. 2010) to detect significant genetic differences between S. suckleyi and S. acanthias, which has prompted the resurrection of the taxon S. suckleyi (Ebert et al. 2010).

The North Pacific spiny dogfish S. suckleyi is endemic to the North Pacific Ocean (Ebert et al. 2010) and is widely distributed as far north as the Gulf of Anadyr in the Bering Sea on the Asian coast and Kotzebue Sound in the Chukchi Sea in American waters. The southern edge of its range extends to the northern part of the East China Sea, the Hawaiian Islands, and the southern tip of Baja California (Mecklenburg et al. 2002, Glebov et al. 2010). It is also known that this shark inhabits mostly coastal areas but occasionally occurs far from shore (Nagasawa et al. 1996, Melnikov 1997). S. suckleyi is a commercially important target species in Japan, the USA and Canada (Osipov 1986). In the Russian waters of Primorye and Sakhalin, there was a specialized fishery for this species before World War II which harvested several tens of thousands of metric tons annually (Kaganovskaya 1937, Fadeev 1984).

Despite a wide distribution, high commercial importance, and a long history of harvesting S. suckleyi, its spatial and vertical distribution patterns within its range are still poorly understood and data on size composition remain scarce (Fadeev 1960, Alverson and Stansby 1963, Ketchen 1986, Allen and Smith 1988, Nakano and Nagasawa 1996, Melnikov 1997, Brodeur et al. 2009, Palsson 2009, King and McFarlane 2009, Beamish and Sweeting 2009, Conrath and Foy 2009, Orlov and Tokranov 2009, Tribuzio et al. 2009, Nakano et al. 2009). Moreover, most of the publish sources referred above do not cover the whole range of the species and in many cases are based on limited data.

Maps of the distribution of S. suckleyi in the western Bering Sea and northwestern Pacific based on long-term TINRO-Center data were recently published (Shuntov and Bocharov 2005, 2006). The data presented in these publications were processed with GIS technology in $1^{\circ}$ rectangles, and therefore only reflect common patterns of the species' distribution. Moreover, these maps only include information on S. suckleyi caught with midwater trawls in upper layers for the period from 1979 to 2004, and do not account for its deeper pelagic and demersal distribution. Finally, the above mentioned maps are restricted to the northwestern Pacific, and do not provide any information regarding the species' distribution in the northeastern part of the Pacific Ocean.

The aim of this paper was to document the distribution of S. suckleyi in the North Pacific Ocean, analyze seasonal and long-term population changes, compare the size composition from different fishing gears, and report the physiological condition of selected individuals.

\section{MATERIALS AND METHODS}

Data were collected during trawl surveys and commercial fishing operations by bottom and pelagic trawls and salmon driftnets in various regions of the North $\mathrm{Pa}$ cific carried out by employees of the Pacific Scientific Research Fisheries Center (TINRO-Center, Vladivostok, Russia), Alaska Fisheries Science Center (AFSC, Seattle, USA, http://www.afsc.noaa.gov/RACE/ groundfish/survey_data), Russian Federal (VNIRO, Moscow, Russia), Sakhalin (SakhNIRO, YuzhnoSakhalinsk, Russia) and Kamchatka (KamchatNIRO, Petropavlovsk-Kamchatsky, Russia) research institutes of fisheries and oceanography, and also by US observers on board commercial trawlers, longliners, and pot fishing vessels (http://www.afsc.noaa.gov/FMA/fma database.htm). The data we used were extracted from the above data sets. We only considered the catches in which S. suckleyi was recorded.

AFSC data contained 29 records (May-October, 1983-2006) off the Aleutian Islands, 10 records (JuneJuly, 1983-2004) in the Eastern Bering Sea and 1392 records (May-September, 1984-2007) of S. suckleyi in the Gulf of Alaska. Data from US observers on board commercial vessels include 3881 captures of this species in fishing gears in Alaskan waters all year round (no data on capture depth or month are available). The data from the TINRO-Center include 1249 records of S. suckleyi from bottom (caught with bottom trawls) and pelagic (caught with midwater trawls) surveys performed in the entire North Pacific Ocean all year round from 1970 to 2007 (including waters of Japan, USA and Canada before the establishment of EEZs). The staff of SakhNIRO and KamchatNIRO reported 379 records of this species in driftnet catches off the Kuril Islands and Kamchatka from July-August 2006-2008. We also used 43 S. suckleyi records from bottom trawls off the Kuril Islands and Kamchatka from August to December 1993-2005 compiled by employees of VNIRO, SakhNIRO and KamchatNIRO. All available data were used to analyze seasonal and decadal changes in the spatial distribution of $S$. suckleyi. The spatial distribution maps were drawn using the SURFER 8 software (Golden Software, Inc. 2005).

In total, data from 7059 catches of S. suckleyi taken by various fishing gears, including 3178 with depth records, were analyzed. All catches with a reported bottom depth and trawl depth were conventionally 
classified as "bottom" if the bottom depth and trawl depth coincided, or "pelagic" if the bottom depth and trawl depth differed by $10 \mathrm{~m}$ or more. Since the duration of trawling in the surveys varied substantially, all catches were recalculated per standard hour trawling.

All data with reported capture depths were analyzed to determine features of the vertical distribution of $S$. suckleyi in terms of percent of captures and average catch rate. Percent capture was calculated by dividing the number of fish caught within a certain depth range by the total number of fish caught (in the water column or near the bottom), multiplied by 100 .

The analysis of the size composition was based on measuring the total length (TL) of 413 individuals from driftnet catches, 328 individuals from midwater trawl catches, and 722 individuals from bottom trawl catches.

The length-weight relationship was based on length and weight measurements of 536 specimens with TLs ranging from 20 to $138 \mathrm{~cm}$ caught with different fishing gears. Using all available data on the length $(T L)$ and weight $(W)$ of $S$. suckleyi, Microsoft Office Excel 2003 was used to calculate and plot length/weight relationships and the condition factor $\left(C F=W 100 / T L^{3}\right)$ in order to determine whether there were any ontogenetic or seasonal changes.

Relationships between $T L$ and capture depth and between $T L$ and month were compared using Spearmen's rank correlation $\left(r_{s}\right)$, with a confidence level $(p)$ of 0.05 .

\section{RESULTS}

\section{Spatial distribution}

According to our data (Fig. 1a), S. suckleyi is commonly caught near the bottom off the coast of Primorye and southwestern Sakhalin, the southern Kurils, the Aleutian Islands, the eastern Bering Sea, the Gulf of Alaska, and off the west coast of the USA and Canada (southward of the Gulf of Alaska). It is also common in bottom catches on the Emperor Seamounts, and the seamounts south of the Gulf of Alaska. There is a notably low occurrence of this species near the bottom in waters of the central and northern Kurils, East Kamchatka and the western Bering Sea.

In the water column, this species most frequently occurs in the northern part of the Sea of Japan, off northeastern Hokkaido, off the Kuril Islands and southeastern Kamchatka, the eastern part of Bristol Bay, the northern Gulf of Alaska, and off the west coast of the USA and Canada, south of Vancouver Island (Fig. 1b). In the Sea of Okhotsk this species is most common near the southern Kurils and southern Sakhalin. Captures in the Bering Sea were recorded up to Navarin Cape. On rare occasions this dogfish was found in midwater depths in more remote areas, mostly over seamounts, e.g. the Emperor Seamounts or seamounts south of the Gulf of Alaska.
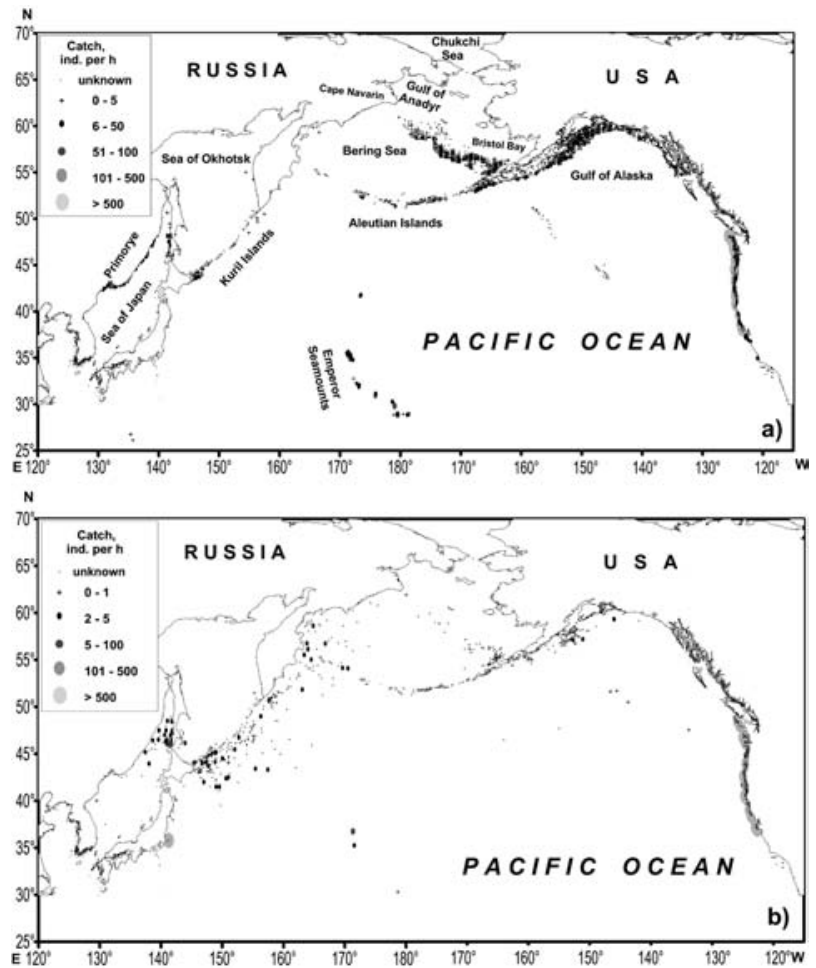

FIG. 1. - Distribution and relative abundance of Squalus suckleyi in the North Pacific based on bottom trawl (a) and pelagic trawl (b) catch data combined.

The distribution of S. suckleyi shows a maximum abundance near the west coast of USA and Canada, where most pelagic trawl catches exceeded 100 ind./h (Fig. 1b). In the other regions, the pelagic trawl catches seldom included more than 2-5 fish. The bottom trawl catches (Fig. 1a) were also highest near the west coast of the USA and Canada where most were above 100 ind./h. In other regions the bottom trawl catches contained fewer than 50 individual dogfish.

According to the AFSC data (Fig. 2a), S. suckleyi in the Gulf of Alaska is most abundant in the central area where its density often exceeded 1000 fish per hectare. In the western part of the Gulf of Alaska, off the eastern Aleutian Islands and the southeastern Bering Sea, this species is relatively scarce, and its aggregations there were mostly less than 50 ind./ha. The data from the US observers collected from commercial fishing vessels (Fig. 2b) also indicate that the highest abundance of $S$. suckleyi is in the central Gulf of Alaska where the proportion in most catches was over $1 \%$. Off the Aleutian Islands and in the eastern Bering Sea this dogfish made up less than $1 \%$ of catches.

Near the Asian coast S. suckleyi was most abundant in the Pacific waters east of the central part of the Kuril Islands and southeastern Kamchatka (Fig. 2c), where driftnet catches often exceeded 30 fish per set.

As S. suckleyi performs seasonal migrations, the annual patterns of the spatial distribution vary considerably. Catches during January-March near the Asian coast occurred in waters south of Iturup Island (south- 


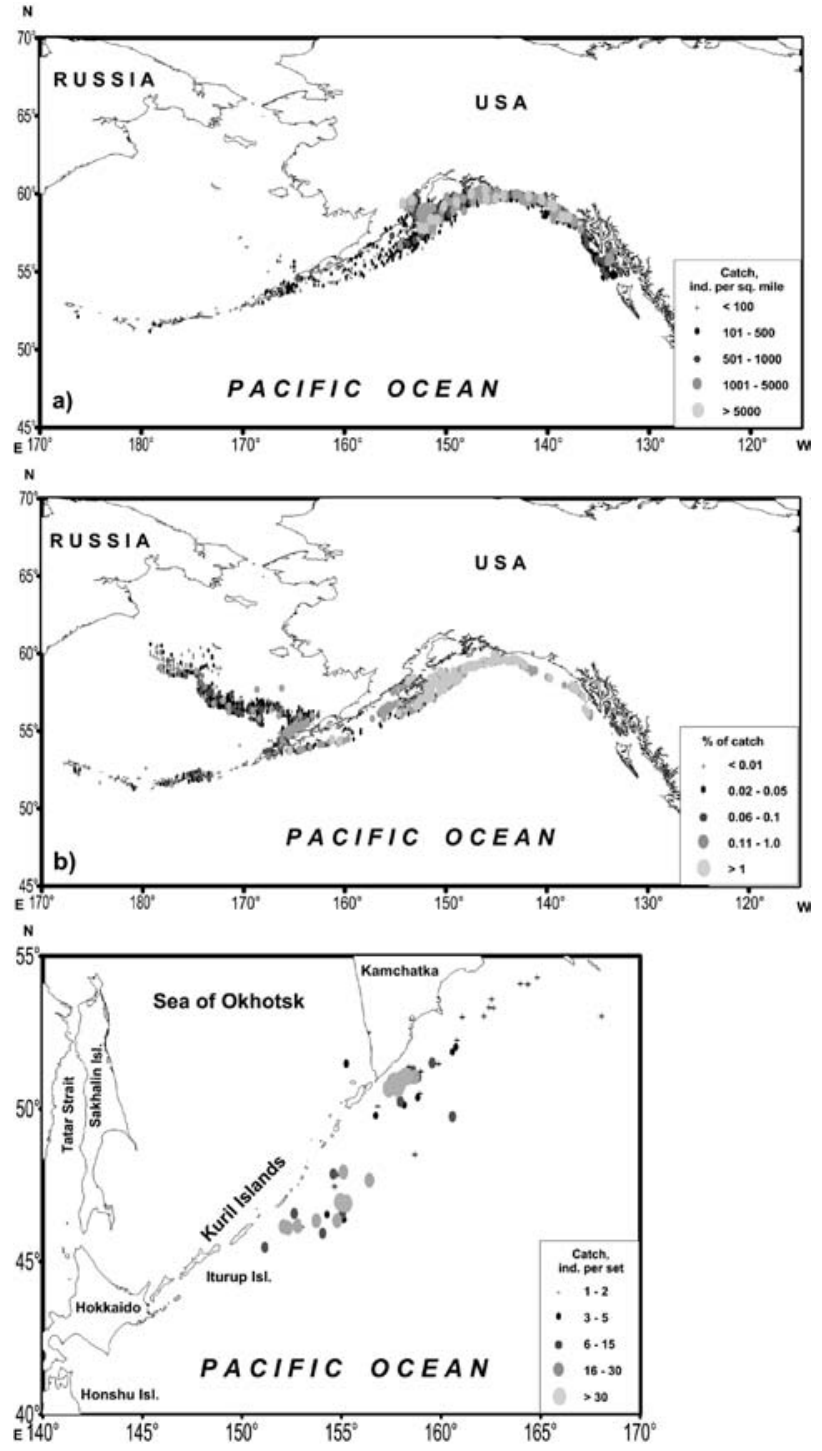

FIG. 2. - Distribution and relative abundance of Squalus suckleyi in the northeastern Pacific based on data of AFSC bottom trawl surveys (a) and US observers on board commercial fishing vessels (b) and in the Pacific off the Kuril Islands and Kamchatka based on the data of Russian observers of salmon driftnet fisheries (c).

ern Kurils), where the dogfish may be wintering. In the northeastern Pacific during this period S. suckleyi is more abundant in the Gulf of Alaska, especially in its central part (Fig. 3a). Migrating to the north during April-June, S. suckleyi appears in Primorye and the northern Sea of Japan in great numbers (Fig. 3b). The dogfish moves from the central part of the Gulf of Alaska in large numbers to its western part and penetrates the southeastern Bering Sea. At the same time, S. suckleyi occupies waters off the US west coast south of Vancouver Island, probably migrating from more southerly parts of the Oregon and California waters. During July to September the dogfish is distributed most widely in the North Pacific (Fig. 3c). In this period it appears in the southwestern Sea of
Okhotsk, in the Pacific waters of the Kurils, and in the western Bering Sea up to Navarin Cape. In the waters along the USA shores, the highest abundance in these months is found in the Gulf of Alaska, perhaps consisting of dogfish migrating from the more southern parts of the coastal waters. The spatial distribution changes insignificantly during October-December (Fig. 3d), though the lower number of captures in the western Bering Sea and the Gulf of Alaska and the appearance of the fish off the Honshu coast might signal the beginning of a southerly shift.

Our multi-annual data revealed decadal variations in the spatial distribution of S. suckleyi. The 1974-1980 data are the least representative (about 300 captures) as there was little research carried out at that time. Nevertheless, these data show the most frequent occurrence of the species near the US west coast south of Vancouver Island, in southern Kuril waters and on the Emperor Seamounts (Fig. 4a), i.e. in the southern part of the species' range. In addition, the period of 1981-1990 was marked by the frequent occurrence of the species near the Primorye shores and in Tatar Strait (northern Sea of Japan), near the southern Kurils, the eastern part of the Aleutian chain and the west coast of the USA (Fig. 4b). Catches of this species were recorded in these years both in the western and eastern parts of the Bering Sea. The next decade did not differ radically from the previous one in terms of distribution pattern (Fig. 4c), except for a higher occurrence of S. suckleyi in the southeastern Bering Sea. The spatial distribution pattern of this species has changed significantly over the last decade (Fig. 4d). Unlike the previous decade, the dogfish began to appear in both parts of the Bering Sea up to Navarin Cape.

\section{Vertical distribution}

According to our data the highest frequency of $S$. suckleyi in the water column (about $80 \%$ ) is found in the upper $25 \mathrm{~m}$ layer (Fig. 5a). Besides this stratum, large catches of over 12 individuals per hour haul were also recorded at 126-175 m, though the percentage of its captures at this depth did not exceed 3\%. This result might be due to a relatively small sample size (258 individuals within 126-175 m vs. 2612 fish within 0-25 $\mathrm{m})$. Conversely, large occasional catches of S. suckleyi in some locations could be attributed to the aggregative behaviour of this shark.

The diagram of the vertical distribution of S. suckleyi near the bottom also shows two peaks (Fig. 5b). The maximum capture rate of $46.5 \%$ occurred more often at depths less than $50 \mathrm{~m}$ and the average catches were nearly $19 \mathrm{fish} / \mathrm{h}$. The largest catches of 56-77 individuals per hour were observed from 101 to $200 \mathrm{~m}$ depth, where occurrence (percent of captures) made up about $49 \%$. The presence of two peaks (number of captures and catch rate) can also be explained by differences in seasonal habitation depths. The low percent of captures and catch rate in the 51-100 m depth range are 

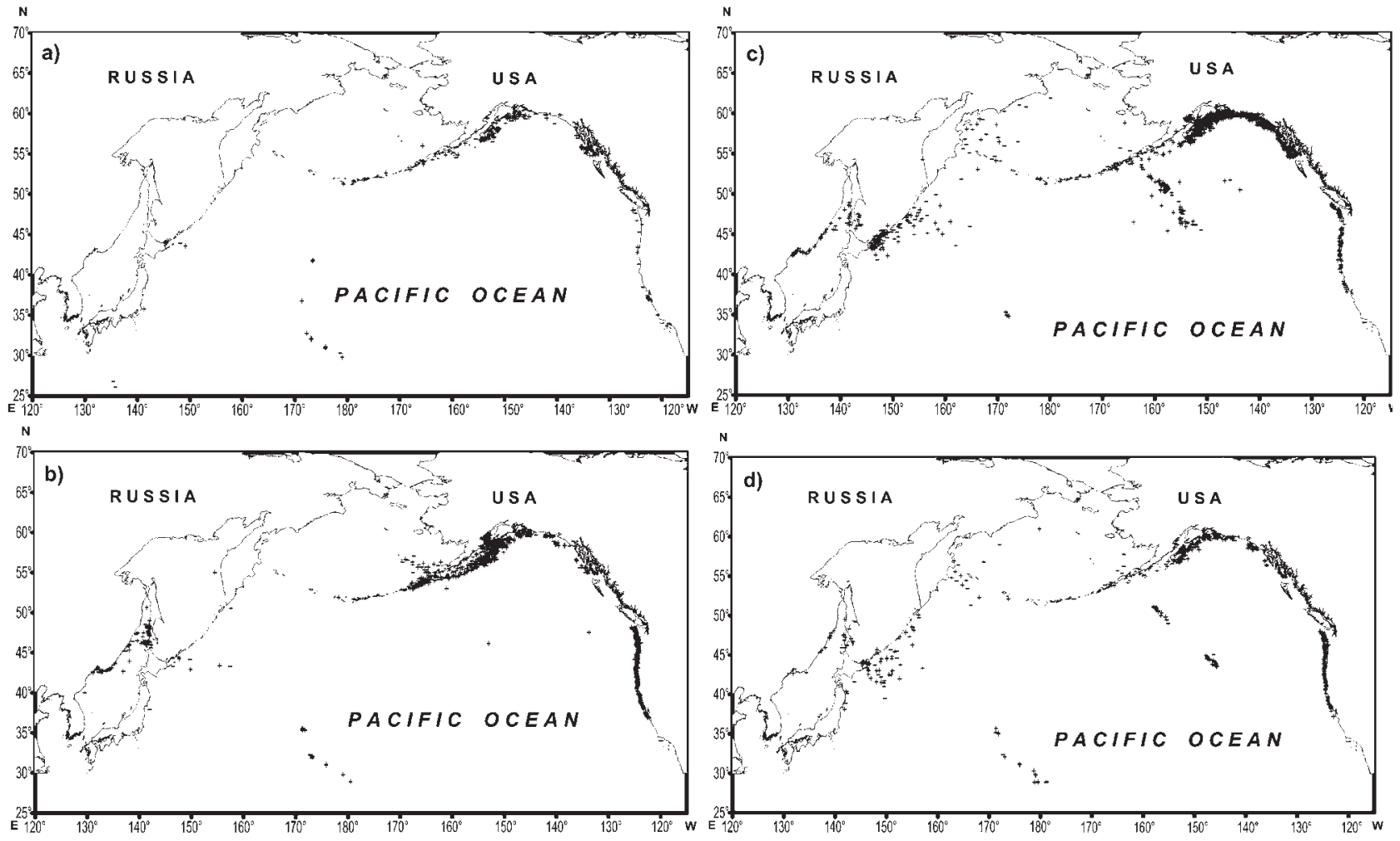

FIG. 3. - Capture sites of Squalus suckleyi in the North Pacific by seasons, 1970-2008: January-March (a), April-June (b), July-September (c), October-December (d).
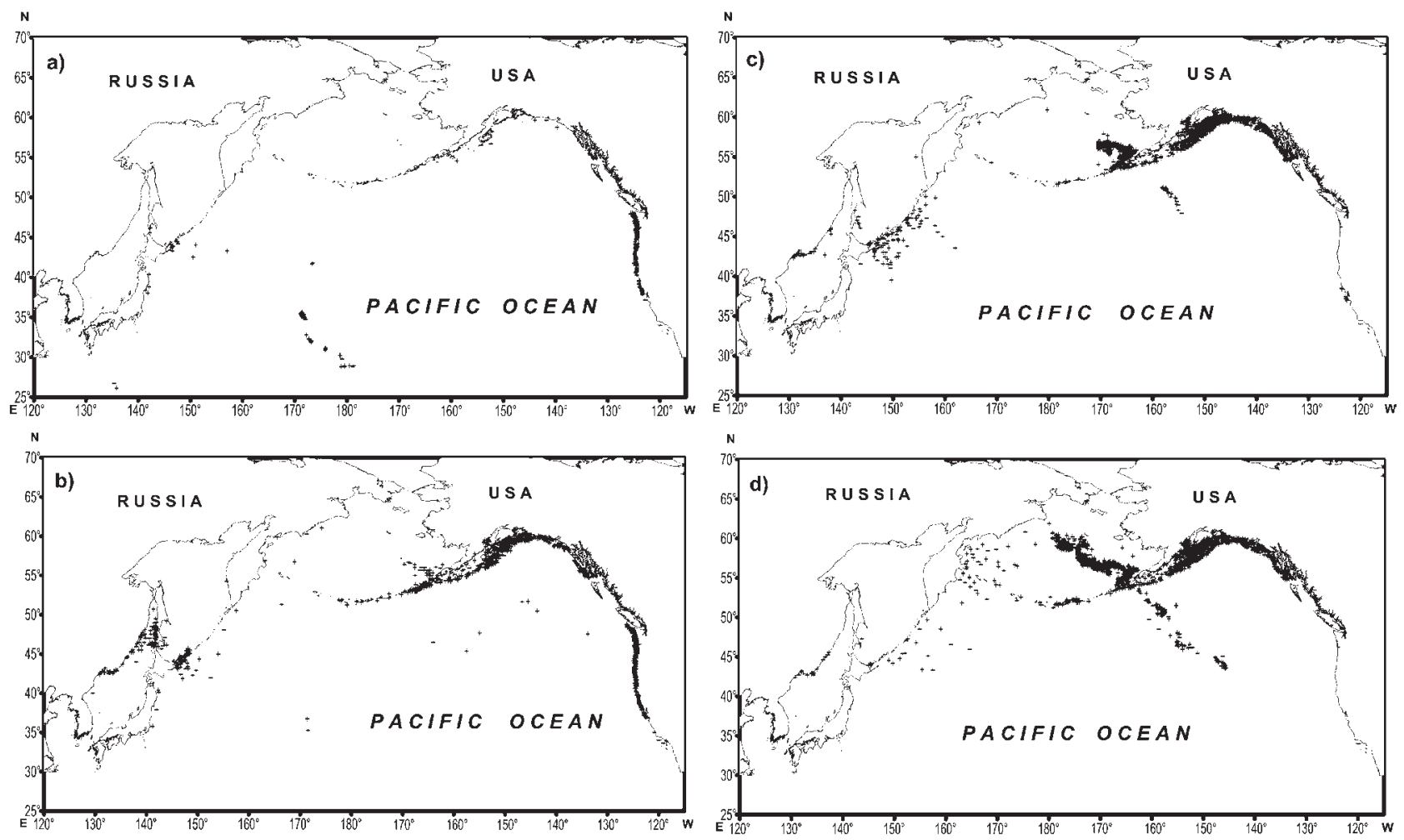

FIG. 4. - Capture sites of Squalus suckleyi in the North Pacific by decades, 1970-2008: in 1970-1980 (a), in 1981-1990 (b), in $1991-2000$ (c), and in 2001-2008 (d). 

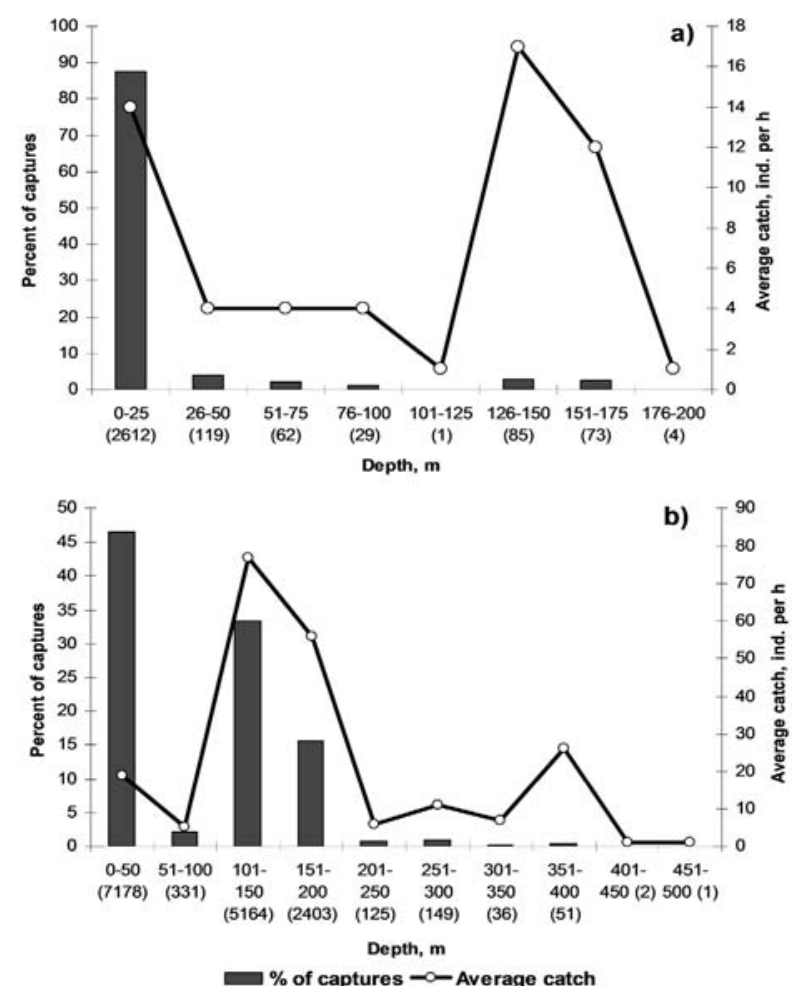

FIG. 5. - Vertical distribution of Squalus suckleyi in the North Pacific: (a) in the water column, and (b) near the bottom (number of fish caught within each depth range is shown in brackets).

probably related to a small sample size at these depths (331 ind. vs. 7188 ind. at 0-50 m, 5164 ind. at 101-150 $\mathrm{m}$ and 2403 ind. at $151-200 \mathrm{~m}$ depth).

The data on seasonal changes in $S$. suckleyi capture depths (Fig. 6a) show that its depth range widens from winter to summer, is widest during the summer-autumn period and then decreases again during winter. During the summer and autumn periods, capture depths varied from 385 to $592 \mathrm{~m}$, while in winter and spring the depth ranged between 228 and $349 \mathrm{~m}$.

Our data based on US bottom trawl surveys in Alaskan waters (Fig. 6b) show that catches of S. suckleyi near the bottom are lowest at night (9 p.m. to 6 a.m.) and highest during the day. This indicates that the fish is scarce near the bottom during dark hours, when it rises to the surface.

The US bottom trawl survey data show that $S$. suckleyi in Alaskan waters occurs at near-bottom temperatures of $0^{\circ}$ to $12.7^{\circ} \mathrm{C}$ (Fig. 6c). A well-pronounced relationship between the size of catches and bottom temperature can easily be seen $\left(R^{2}=0.78\right)$; the higher the temperature, the larger the catches of $S$. suckleyi. Maximum catches were obtained when the near-bottom temperature was above $8^{\circ} \mathrm{C}$.

\section{Length and weight}

According to our data, the maximum mean $T L$ of S. suckleyi was found in driftnet catches from the $\mathrm{Pa}-$ cific waters off the Kurils and Kamchatka (Fig. 7a). These catches consisted of 55-110 cm dogfish (average $75.3 \mathrm{~cm}$ ) and the prevalent size ranges were $67-80 \mathrm{~cm}$ $(69.3 \%)$ and $84-87 \mathrm{~cm}(9.7 \%)$.

S. suckleyi caught by midwater trawls were smaller in general (Fig. 7b). The size range in these catches was $20-138 \mathrm{~cm}$ (average $68.6 \mathrm{~cm}$ ) and the $59-75 \mathrm{~cm}(52.7 \%)$ and $78-80(8.8 \%)$ length classes were predominant.

In bottom trawl catches taken in the northwestern Pacific (Fig. 7c) S. suckleyi was represented by individuals with lengths of 22-140 cm (average $69.1 \mathrm{~cm}$ ), and three size classes were most prevalent: $50-72 \mathrm{~cm}$ (52.5\%), 75-82 $\mathrm{cm}(19.1 \%)$ and 90-92 $\mathrm{cm}(3.6 \%)$. The northeastern Pacific bottom trawl catches included smaller individuals (Fig. 7d) of 30-105 cm (average $57.1 \mathrm{~cm})$ where sharks of 40 to $75 \mathrm{~cm}(88.7 \%)$ prevailed.

Our data show that the mean size of dogfish increases to some extent with depth, from $68.7 \mathrm{~cm}$ at $100 \mathrm{~m}$ to $74.0-81.7 \mathrm{~cm}$ at $400-500 \mathrm{~m}$ (Fig. 8a). Since
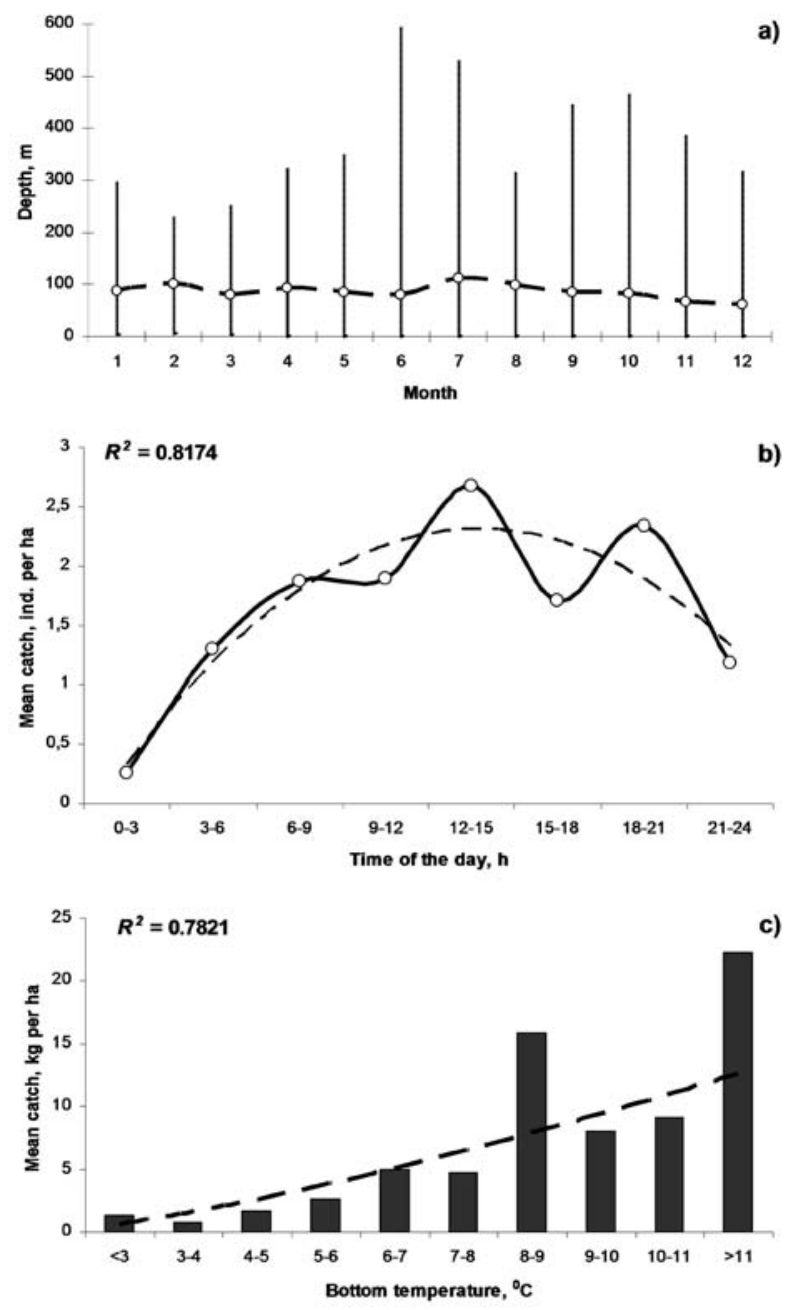

FIG. 6. - Seasonal changes of Squalus suckleyi capture depths in the North Pacific (a), its vertical diurnal migrations (b) and bottom temperature-dependant distribution (b) in the northeastern Pacific (open circles, mean values; dashed line, trend; vertical bars, variations). 

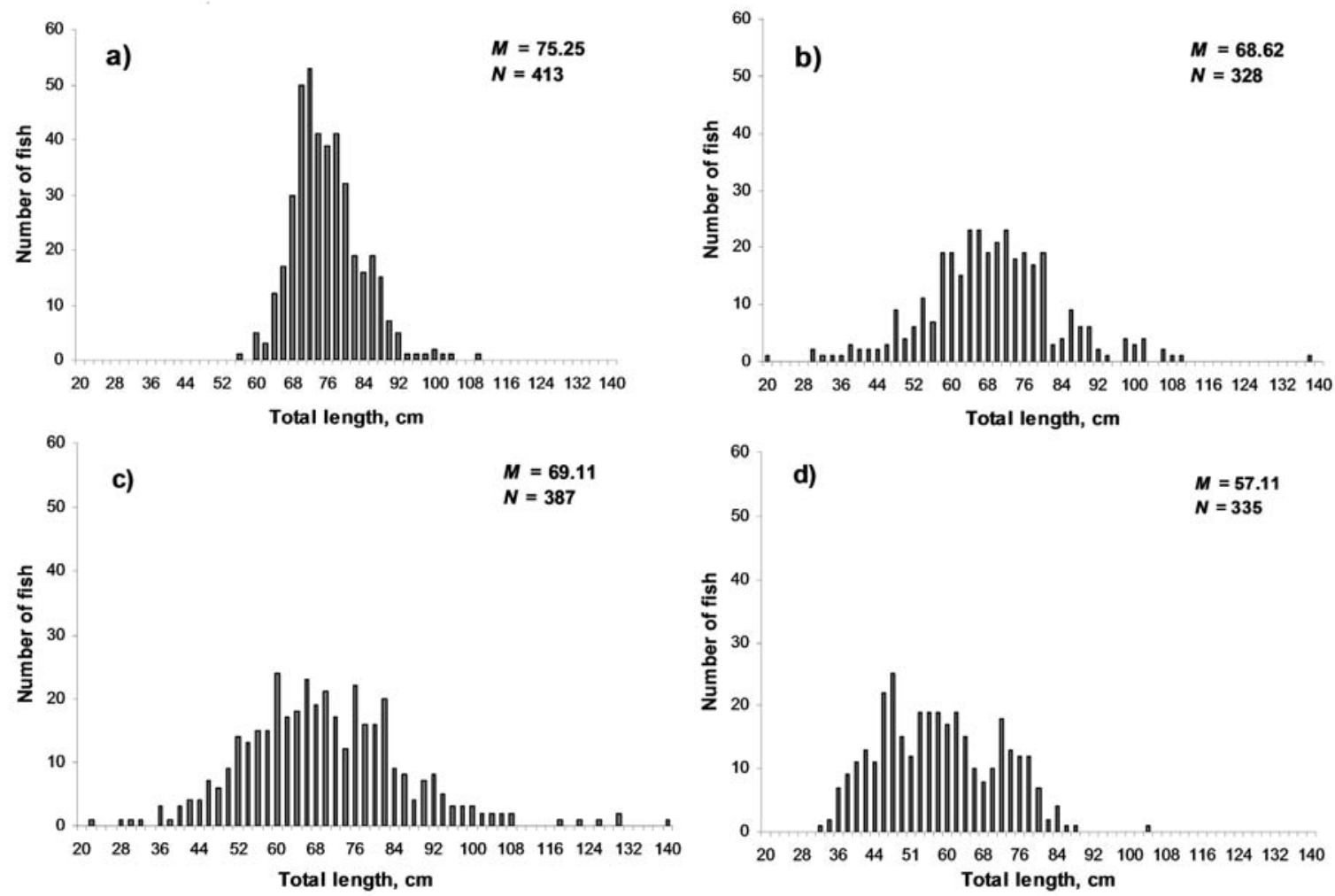

Fig. 7. - Size composition of Squalus suckleyi in the catches of (a) salmon driftnets in the Pacific off the Kuril Islands and Kamchatka, (b) pelagic trawls in the North Pacific, (c) bottom trawls in the northwestern Pacific, and (d) bottom trawls in the northeastern Pacific $(M$, mean length, $\mathrm{cm} ; N$, number of fish measured).

$22-140 \mathrm{~cm}$ dogfish are caught at shallower depths and individuals of $61-100 \mathrm{~cm}$ are caught at $400 \mathrm{~m}$, the size range appears to narrow with increasing depth. It should be noted that this pattern was not statistically significant $\left(r_{s}=0.50, r_{c r}=0.94\right)$ and therefore has to be considered with caution. Our data show that the mean size of $S$. suckleyi did not change significantly $\left(r_{s}=\right.$ $-0.12, r_{c r}=0.58$ ) throughout the year (Fig. 8b) and varied within 65.8 to $75.9 \mathrm{~cm}$. Moreover, the narrowest size range was typical of the period of November through March (minimum 61.5-91.0 $\mathrm{cm}$ in January), while in April to September the size range was much broader (maximum $20-138 \mathrm{~cm}$ in June).

The relationship between total length and body weight of S. suckleyi can be expressed with the following equation (Fig. 9a):

$$
W=0.0001 T L^{2.2837} \text {, }
$$

where $W$ is body weight $(\mathrm{kg})$, and $T L$ is the total length (cm).

The condition factor in S. suckleyi (Fig. 9b) generally decreased with somatic growth. The maximum values of the condition factor were generally found in sharks smaller than $50 \mathrm{~cm}$. The lowest condition factor was observed in individuals of $50-90 \mathrm{~cm}$. The highest condition factor for $S$. suckleyi was found in the winter and summer months (December-February and June-
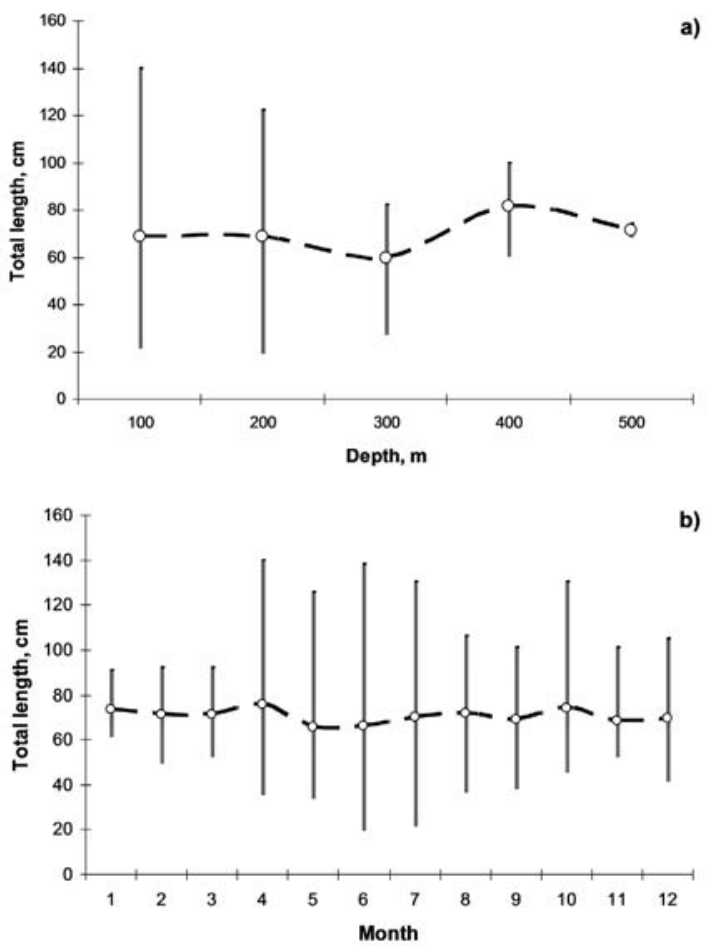

FIG. 8. - Bathymetric (a) and seasonal (b) changes of Squalus suckleyi sizes in the North Pacific (open circles - mean values, dashed line - trend, vertical bars - variations). 

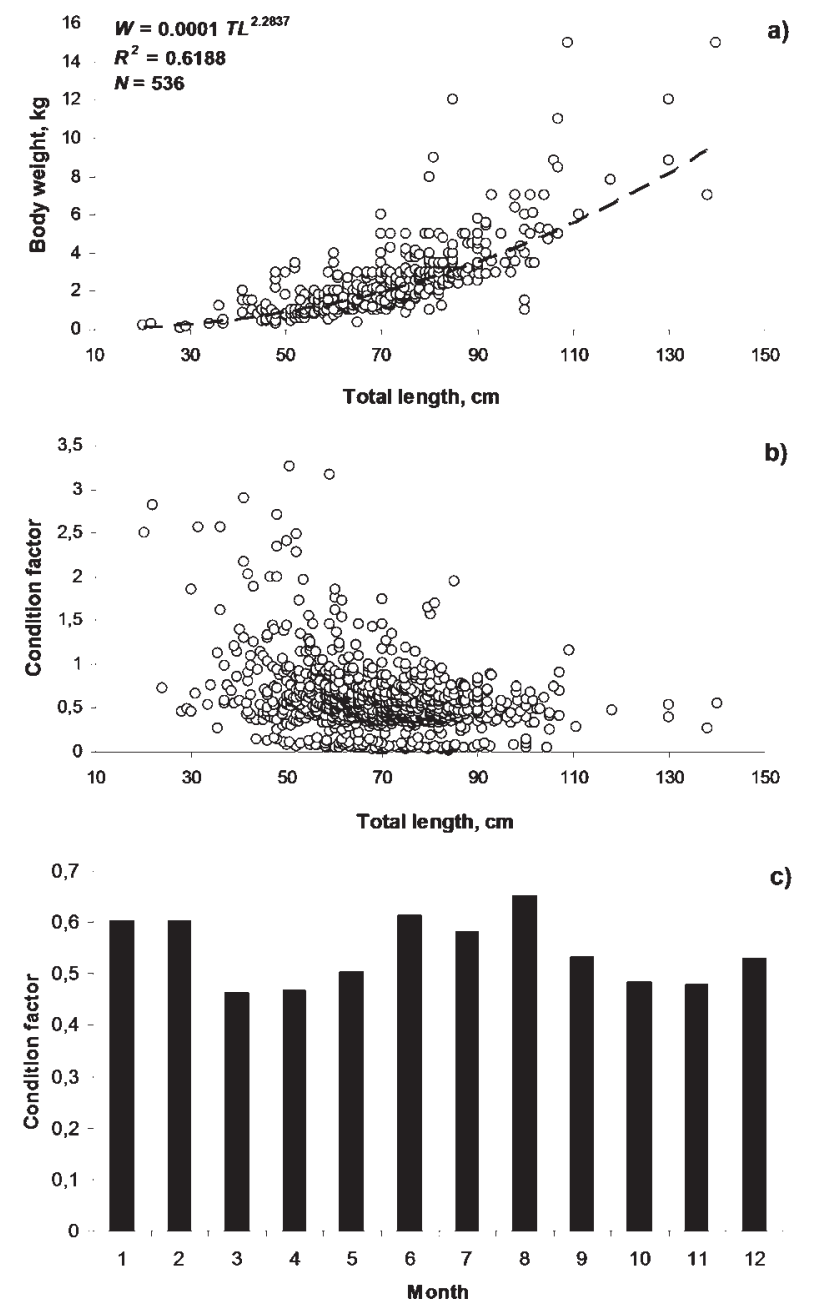

FIG. 9. - Squalus suckleyi length-weight relationship (a), ontogenetic (b) and seasonal (c) changes of its condition factor in the North Pacific ( $W$, body weight; $T L$, total length; $N$, number of fish examined).

August) (Fig. 9c), whereas the lowest values occurred in spring and autumn.

\section{DISCUSSION}

\section{Spatial distribution}

The spatial distribution patterns of $S$. suckleyi within its range were poorly understood until the present. Our study presents more detailed information on the spatial patterns of the species' distribution and its seasonal and multi-annual variations.

S. suckleyi undergoes seasonal feeding migrations. In spring, the increasing inshore water temperature is accompanied by the movement of individuals to the northern edge of the species' range. In autumn, when coastal waters cool, S. suckleyi moves south. During these seasonal migrations, individuals move north along the coasts of Primorye, Japan, and Kuril Islands, penetrating as far as the Kamchatkan waters of the $\mathrm{Pa}$ - cific and the southwestern Bering Sea (Osipov 1986). Migrations of the species in the northeastern Pacific have only been studied within the waters of British Columbia, and the neighbouring US states of Oregon and Washington (Ketchen 1986, Mc Farlane and King 2003, 2009, Taylor et al. 2009). In general, our data support previous studies of $S$. suckleyi migrations but provide more details of this process.

The low occurrence of $S$. suckleyi near the bottom in waters of the central and northern Kurils, eastern Kamchatka and the western Bering Sea is probably due to the feeding on Pacific salmon, Oncorhynchus spp. (Melnikov 1997).

In most cases S. suckleyi was found in coastal waters, though catches far from the coast were not rare, as shown in previously published data (Parin 1968, Ketchen 1986, Nagasawa et al. 1996, Melnikov 1997). Captures of this species in the high seas east of Hokkaido, the Kurils and East Kamchatka are probably explained by the presence of the Pacific salmon, the main food of spiny dogfish during the feeding period (Beamish et al. 1992, Melnikov 1997).

Osipov (1986) indicated that S. suckleyi is most abundant in the northeastern Pacific, especially in waters of Canada and Oregon/Washington. This species is continuously distributed along the entire US and Canadian west coast (Allen and Smith 1988) but is most abundant in waters off British Columbia and Washington, declining substantially southward through Oregon and California (Alverson and Stansby 1963, Ketchen 1986, Brodeur et al. 2009). We have no data from Canadian waters but it is known that the centre of $S$. suckleyi abundance appears to be in the British Columbia - Washington region $\left(48^{\circ} \mathrm{N}-54^{\circ} \mathrm{N}\right)$ including the inshore waters of the Strait of Georgia and Puget Sound (Ketchen 1986). A study by Brodeur et al. (2009) based on NMFS West Coast triennial shelf groundfish surveys from 1977 to 2004 showed that the largest catches of S. suckleyi in US waters occurred off the coast of Washington $\left(46^{\circ} \mathrm{N}-48^{\circ} \mathrm{N}\right)$, and the catch gradually decreased to the south. Our data corroborate these findings regarding the high abundance of $S$. suckleyi off the US west coast. Our data also support the results of prior studies that have shown a high abundance of S. suckleyi in the waters of Hokkaido, Sakhalin, Primorye and the Kuril Islands (Osipov 1986, Melnikov, 1997, Parin 2001, Nakano et al. 2009). Summing up the information on this species' distribution in the North Pacific, we should note that, on the whole, our data agree with those published previously. Regarding the overall distribution of $S$. suckleyi we agree with Parin's (2001) characterization of the range as "borealsubtropical", in contrast to Fedorov (2000) who characterized the range as "south-boreal".

There were shark gillnet, bottom gillnet, fixed trap, trawl and hook-and-line fisheries in the 1920s and 1930s in the waters of Primorye and Sakhalin with annual catches of 22 to 65 thousand metric tons (Kaganovskaya 1937). The catches of this dogfish taken in 
Terpeniya Bay (southeastern Sakhalin) in 1954-1955 exceeded 1 metric ton per hour trawl haul (Fadeev 1960). Our data do not show such dense aggregations of the species in either of these regions during the most recent 40 year period, probably due to a significant decline in abundance caused by excessive fishing. In Japanese waters there was also a notable decline in $S$. suckleyi catches in the early 1950s (Orlov and Shevernitsky 2008, Nakano et al. 2009). The present status of its abundance in the northwestern Pacific is unknown. There is an ongoing increase in abundance in the Gulf of Alaska, which began in the late 1990s and has been attributed to climate change (Wright and Hulbert 2000, Conrath and Foy 2009).

Long-term changes in the spatial distribution of $S$. suckleyi in the North Pacific had not been examined prior to our study. Our analysis indicates that during the recent decade the range of this dogfish has expanded greatly to the north on both sides of the Bering Sea, up to Navarin Cape and even to the Gulf of Anadyr (Glebov et al. 2010). Our finding agrees with that of Wright and Hulbert (2000) regarding the increase in the number of this dogfish in the Gulf of Alaska since the late 1990s, which is probably a result of the well-documented climate regime shift in the North Pacific over the past century (McFarlane et al. 2000, Benson and Trites 2002, Schwing et al. 2002, King 2005). It should be noted that the lower numbers of captures of this species after 1990 in the Tatar Strait are probably because there are only limited data from this region during this period. The virtual absence of captures of S. suckleyi on our maps (Fig. 4) near the west coast of the USA and Canada in the same period is because the US and Canadian survey data for this time were not available. However, these data were recently published in part by Brodeur et al. (2009) and serve to supplement the missing information from this area. Their data show that prior to 1990 the largest $S$. suckleyi catches occurred north of $47^{\circ} \mathrm{N}$, and that subsequently catch rates in this area gradually decreased. Taken into account with our data, which show a significant northward range extension for S. suckleyi during the past decade, it could be suggested that the decreasing abundance of S. suckleyi in Washington waters reported by Brodeur et al. (2009) is related to a northward shift in distribution caused by climate change.

\section{Vertical distribution}

The vertical distribution of $S$. suckleyi had not been adequately examined prior to our study. Fedorov (2000) considered this species to be an elitoral (outer shelf) species, whereas Parin (2001) believed it to be epibenthopelagic. There is no single view on the maximum depth it inhabits. Reported maximum depths are: $500 \mathrm{~m}$ (Parin 2001), 700-750 m (Fadeev 1984, Borets 2000), $950 \mathrm{~m}$ (Fedorov 2000, Chereshnev et al. 2001), and $1244 \mathrm{~m}$ (Mecklenburg et al. 2002). Preferred depths are within the range of 50-200 m (Allen and
Smith 1988). In addition, this shark is found mostly at 20-50 m near Sakhalin, 50-150 m in the Gulf of Alaska, and 100-350 m near Vancouver Island (Osipov 1986, Conrath and Foy 2009).

The two peaks in the vertical distribution of S. suckleyi may be related to seasonal variations in habitation depth, i.e. in autumn and winter it generally remains in deeper water compared to the summer depths (Osipov 1986, Chereshnev et al. 2001, Beamish and Sweeting 2009). Specifically, the preferred winter depths in the northeastern Pacific are 350-400 $\mathrm{m}$ and in summer they are 170-300 $\mathrm{m}$ (Osipov 1986). This species remains at depths of 5-70 m during the summer in Primorye, but in winter it shifts to $110-190 \mathrm{~m}$ (Novikov et al. 2002). However, the existence of a second peak in the vertical distribution might also be related to small sample sizes in deeper depth ranges and the aggregative behaviour of S. suckleyi (see above).

Osipov (1986) and Chereshnev et al. (2001) suggested that S. suckleyi performs a diurnal vertical migration, staying near the surface at night and at the bottom during the daytime. However, until our study there was no direct evidence of these diel vertical movements.

Data on the temperature preferences of S. suckleyi were quite scant. According to Osipov's data (1986), the sharks can be found in waters with near-bottom temperatures of $4-17^{\circ} \mathrm{C}$ (mostly $6-14^{\circ} \mathrm{C}$ ). A similar temperature range $\left(6-16^{\circ} \mathrm{C}\right)$ has been reported for Primorye waters (Novikov et al. 2002). Our study presents the first information on bottom temperatures characteristic of $S$. suckleyi habitation in the northeastern Pacific. Our data not only provide new information regarding this species' temperature preferences in the northeastern Pacific but also reveal the relationship between bottom temperature and catch rate.

\section{Length and weight}

Some authors have noted that the size composition of S. suckleyi is subject to seasonal and geographic variability and depends on the depth and fishing gear used (Kaganovskaya 1937, Osipov 1986). Our data did not reveal any significant seasonal changes in S. suckleyi sizes. This could be an artifact of the relatively small sample size (1463 ind. measured) recorded over a long period of time (1970-2007) and over a wide geographic coverage (the entire North Pacific).

S. suckleyi length frequency data for the North Pacific were rather limited and fragmentary until recently. Only five recently published papers (Brouder et al. 2009, Palsson 2009, King and McFarlane 2009, Beamish and Sweeting 2009, Tribuzio et al. 2009) contain information on length frequencies of this dogfish from catches made with various fishing gears. These data, however, are only from the west coast of the USA and Canada. In general, individuals of 80$90 \mathrm{~cm}$ are taken most frequently in the North Pacific (Fadeev 1984). 
The largest specimens of S. suckleyi were captured in salmon driftnet catches, probably because these nets are size-selective. During the period of targeted fishing in the Sea of Japan, the smallest individuals were taken in fixed traps, while the largest ones were caught with drag seines and shark nets (Osipov 1986). In Primorye waters the mean size of dogfish in catches of fixed traps and Japanese sardine (iwasi) nets was areadependent, ranging from 48 to $72 \mathrm{~cm}$, whereas the size ranged from 80 to $100 \mathrm{~cm}$ in bottom gillnet catches (Kaganovskaya 1937).

On the high seas of the northwestern Pacific S. suckleyi lengths in midwater trawls ranged from 55 to 105 $\mathrm{cm}$ (average $73.5 \mathrm{~cm}$ ), and specimens ranging from 60 to $75 \mathrm{~cm}$ were more prevalent (Melnikov 1997). Smaller individuals were taken in midwater trawls in the waters of British Columbia, Oregon and Washington with over half of the specimens having a $T L$ of less than $60 \mathrm{~cm}$ (Beamish and Sweeting 2009, Brodeur et al. 2009). The smaller size of dogfish caught off the west coast of the USA and Canada might be the result of intensive fishing pressure over a long period of time (Ketchen 1986).

According to Osipov (1986), 27-103 cm S. suckleyi were caught with bottom trawls in the northeastern Pacific. The mean length ranged between 61 and $90 \mathrm{~cm}$, depending on the region, season and depth. Data summarized for 23 years (1977-2004) of bottom trawl surveys off Oregon and Washington (Brodeur et al. 2009) show that in this area size ranges from 30 to $90 \mathrm{~cm}$ for males and from 30 to $70 \mathrm{~cm}$ for females. As in the case of midwater trawl catches, the difference in fish size between the northwestern and northeastern Pacific is probably caused by intensive fishing in the latter area (Ketchen 1986). As for the Emperor Seamount Chain, the size range of spiny dogfish in bottom trawl catches was $16-87 \mathrm{~cm}$, with an average of 46-64 cm (Osipov 1986).

It is well known that the size composition of $S$. suckleyi varies with fishing depth, though there is disagreement about how this size segregation is structured. Kaganovskaya (1937) postulated that the youngest individuals primarily inhabit the surface waters, while older fish, mostly males, live closer to the bottom. Conversely, Fadeev (1984) stated that juvenile S. suckleyi stay near the bottom while adult individuals are less associated with the bottom. In Puget Sound the size of individuals in bottom trawl catches has been shown to increase with depth (Palsson 2009). Our data show that the mean size of this dogfish increases to some extent with depth, i.e. in agreement with Kaganovskaya (1937) and Palsson (2009).

The size of $S$. suckleyi is also subject to seasonal variation which may be accompanied by changes in sex ratio. Similar changes have been recorded near the American coast off British Columbia, Washington, Oregon and California, in the Sea of Japan, and in the Emperor Seamount Chain (Osipov 1986). The catch composition in foraging areas (Melnikov 1997) suggests that mainly juveniles and mature males mi- grate to the Kuril Islands and Kamchatka, while gravid females remain in the more southerly regions where pupping takes place throughout the summer (Novikov et al. 2002). Our data did not reveal any considerable seasonal changes in $S$. suckleyi size. We also have no data on the sex ratio of this species in the catches. Therefore, it is difficult to hypothesize about the differences between the published data and our results.

The length-weight relationship in S. suckleyi has only been described from Canadian waters (Jones and Geen 1977), with a power coefficient of the lengthweight equation close to 3 (3.03-3.09). With our data, we found a much lower coefficient (2.3), which indicates that the condition factor is considerably lower compared to the previous study conducted in 1977. These differences are probably because our catches consisted to a greater extent of foraging immature fish.

Ontogenetic variation in the condition factor of $S$. suckleyi has not been previously investigated. In the northeastern Pacific, 50\% of males become mature at a $T L$ of $74 \mathrm{~cm}$, while $50 \%$ of females become mature at a $T L$ of about $90 \mathrm{~cm}$ (Tribuzio 2004). The lowest condition factor in our study was observed in immature individuals of 50-90 cm, probably associated with the large expenditures of energy needed for gonad maturation in sharks of this size group.

The seasonal dynamics in the condition factor of S. suckleyi have not been studied. The cause of variation in the condition factor is not entirely clear as yet and is most likely governed by changes in the physiological state of individuals throughout the year (wintering, feeding, maturation, mating, pre-natal stage, birth). Our data show that the condition factor changes with growth. However, like the seasonal variations in the condition factor in other sharks, there is little information available. The Atlantic sharpnose shark, Rhizoprionodon terraenovae, in the Gulf of Mexico has a maximum condition factor in April, followed by a gradual decline to July, and further growth in September (Parsons and Hoffmayer 2005). The smallest values were found during the summer months. The tope shark, Galeorhinus galeus, on the shelf of northern Patagonia shows an increase in condition factor between January and April (no samples were collected later in the year) (Elias et al. 2004). In the Brazilian sharpnose shark, Rhizoprionodon lalandii, off the southern coast of Brazil the condition factor of males remains virtually unchanged throughout the year, but in females it increases gradually from December and peaks in June-July (Andrade et al. 2008). Juveniles of the scalloped hammerhead shark, Sphyrna lewini, in Hawaiian waters exhibit a minimum condition factor in autumn and winter and a maximum value in spring and summer (Duncan and Holland 2006). Stevens and Wiley (1986) also demonstrated that the condition factor in some Australian sharks decreases postnatally.

Sexual dimorphism in the size of S. suckleyi is well documented. Fixed trap catches in Primorye consisted of females with a mean $T L$ of $75.5 \mathrm{~cm}$ versus $50.3 \mathrm{~cm}$ in 
males (Kaganovskaya 1937). Osipov (1986) noted that the mean size of males and females varied depending on the season, fishing gear, site and depth of fishing. In all regions of the Sea of Japan, regardless of gear and month of capture, females were larger than males, except for in Ussuri Bay where in October the average individual length in both sexes was $48 \mathrm{~cm}$ caught with fixed traps. January bottom trawl catches at 280-290 $m$ depth near the Emperor Seamounts showed that females were larger than males (mean $T L 68$ vs. $59 \mathrm{~cm}$ ), yet at $300-380 \mathrm{~m}$ in October the mean length in both sexes was $46 \mathrm{~cm}$. In the northeastern Pacific (British Columbia, Washington, Oregon and California) the mean lengths of males and females in bottom trawl catches varied greatly, with males somewhat larger than females in most cases (Osipov 1986). Since our data mainly included immature individuals, the size differences between sexes were negligible (mean $T L$ 67.9 and $68.7 \mathrm{~cm}$ and mean weight 1536 and $1742 \mathrm{~g}$ for males and females respectively).

\section{CONCLUSIONS}

Squalus suckleyi is most widely distributed in the North Pacific during the summer and autumn months during feeding migrations. A wider distribution of this species in the Bering Sea occurred after 2000, possibly associated with recent climate change.

The occurrence of $S$. suckleyi in the water column and near the bottom considerably differed. In the water column, the maximum catch was observed within the upper $25 \mathrm{~m}$ layer (about 90\%). Near the bottom, this species was most numerous at depths less than $50 \mathrm{~m}$ (over $45 \%$ ) and within a depth range of 101-200 m (about 50\%). During the daytime, the S. suckleyi catch rate was considerably higher than during the night, owing to vertical diel migrations.

This species was caught in water temperatures ranging from 0 to $12.7^{\circ} \mathrm{C}$, with maximum catches observed at temperatures over $8^{\circ} \mathrm{C}$. The size composition of bottom and pelagic trawl catches was similar (mean length 69.1 and $68.6 \mathrm{~cm}$ respectively) while driftnet catches were composed of considerably larger specimens (mean length $75.3 \mathrm{~cm}$ ).

\section{ACKNOWLEDGEMENTS}

The authors would like to express their gratitude to Dr. Charles Cotton (Virginia Institute of Marine Science, Gloucester Point, Virginia, USA) who helped improve the English. We also thank our colleagues from SakhNIRO and KamchatNIRO who shared with us their data on spiny dogfish captures in salmon driftnet catches.

\section{REFERENCES}

Allen M.J., Smith G.B. 1988. Atlas and zoogeography of common fishes in the Bering Sea and northeastern Pacific. U.S. Dept. Commer., NOAA Tech. Rep. NMFS 66: 1-151.
Alverson D.L., Stansby M.E. 1963. The spiny dogfish (Squalus acanthias) in the northeastern Pacific. U.S. Fish Wildlife Serv. Spec. Sci. Rep. Fisher. 447: 1-25.

Andrade A.C., Silva-Junior L.C., Vianna M. 2008. Reproductive bioogy and population variables of the Brazilian sharpnose shark Rhizoprionodon lalandii (Müller \& Henle, 1839) captured in coastal waters of south-eastern Brazil. J. Fish. Biol. 72: 473-484.

Beamish R.J., Tomson B.L., McFarlane G.A. 1992. Spiny dogfish predation on chinook and coho salmon and the potential effects on hatchery-produced salmon. Trans. Am. Fish. Soc. 121: 444-455.

Beamish R.J., Sweeting R.M. 2009. Spiny dogfish in the pelagic waters of the Strait of Georgia and Puget Sound. In: Gallucci V.F., McFarlane G.A., Bargmann G.G. (eds.), Biology and management of dogfish sharks. Am. Fish. Soc., Bethesda, Maryland, pp. 101-118.

Benson A., Trites A.W. 2002. Ecological effects of regime shifts in the Bering Sea and eastern North Pacific Ocean. Fish and Fisheries 3: 95-113.

Bigelow H.B., Schroeder W.C. 1948. Sharks. Fishes of the Western North Atlantic. Mem. Sears Found. Mar. Res. 1: 56-576.

Bigelow H.B., Schroeder W.C. 1957. A study of the sharks of the suborder Squaloidea. Bull. Mus. Compar. Zool. Harvard 117: $1-150$

Borets L.A. 2000. Annotated list of fishes of the Far East seas. TINRO-Center, Vladivostok, 192 p. (In Russian).

Brodeur R.D., Fleming I.A., Bennett J.M., Campbell M.A. 2009. Summer distribution and feeding of spiny dogfish off the Washington and Oregon coasts. In: Gallucci V.F., McFarlane G.A., Bargmann G.G. (eds.), Biology and management of dogfish sharks. Am. Fish. Soc., Bethesda, Maryland, pp. 39-51.

Chereshnev I.A., Volobuyev V.V., Khovansky I.E., Shestakov A.V. 2001. Inshore fishes of the Northern Sea of Okhotsk. Dal'nauka, Vladivostok, 196 p. (In Russian).

Clemens W.A., Wilby G.V. 1946. Fishes of the Pacific coast of Canada. Bull. Fish. Res. Bd. Canada 68: 1-368.

Conrath C.L., Foy R.J. 2009. A history of the distribution and abundance of spiny dogfish in Alaska waters. In: Gallucci V.F., McFarlane G.A., Bargmann G.G. (eds.), Biology and management of dogfish sharks. Am. Fish. Soc., Bethesda, Maryland, pp. 119-126.

Duncan K.M., Holland K.N. 2006. Habitat use, growth rates and dispersal patterns of juvenile scalloped hammerhead sharks Sphyrna lewini in a nursery habitat. Mar. Ecol. Prog. Ser. 312: 211-221.

Ebert D.A., White W.T., Goldman K.J., Compagno L.J.V., DalyEngel T.S., Ward R.D. 2010. Resurrection and redescription of Squalus suckleyi (Girard, 1854) from the North Pacific, with comments on the Squalus acanthias subgroup (Squaliformes: Squalidae). Zootaxa 2612: 22-40.

Elias I., Rodriguez A., Hasan E., Reyna M.V., Amoroso R. 2004. Biological observations of the tope shark, Galeorhinus galeus, in the northern Patagonian gulfs of Argentina. J. Northw. Atl. Fish. Sci. 35: 261-265.

Fadeev N.S. 1960. Some data on spiny dogfish of the eastern coast of southern Sakhalin. Izv. TINRO 46: 217-249 (In Russian).

Fadeev N.S. 1984. Commercial fishes of the North Pacific. DVNC AN SSSR, Vladivostok, 269 p. (In Russian).

Fedorov V.V. 2000. Species composition, distribution and habitation depths of the Northern Kuril Islands fish and fish-like species. In: Kotenev B.N. (ed.), Commercial and biological studies of fishes in the Pacific waters of the Kuril Islands and adjacent areas of the Okhotsk and Bering Seas in 1992-1998. VNIRO Publishing, Moscow, pp. 7-41 (In Russian).

Garman S. 1913. The Plagiostomia. Mem. Mus. Compar. Zool. Harvard 36: $1-515$.

Girard C.F. 1854. Characteristics of some cartilaginous fishes of the Pacific coast of North America. Proc. Acad. Nat. Sci. Philadelphia 7: 196-197.

Glebov I.I., Savinykh V.F., Baitalyuk A.A. 2010. Subtropical migrants in the southwestern Bering Sea. Vopr. Ikhtiol. 50: 480494 (In Russian).

Jones B.C., Geen G.H. 1976. Taxonomic reevaluation of the spiny dogfish (Squalus acanthias L.) in the northeastern Pacific Ocean. J. Fish. Res. Bd. Canada 33: 2500-2506.

Jones B.C., Geen G.H. 1977. Age and growth of spiny dogfish 
(Squalus acanthias) in the Strait of Georgia, British Columbia. Fish. Mar. Serv., Res. Develop. Tech. Rep. 699: 1-16.

Jordan D.S., Evermann B.W. 1896. A check-list of the fishes and fish-like vertebrates of North and Middle America. Rep. U.S. Fish. Comm. 5: 207-584.

Kaganovskaya S.M. 1937. Materials on fisheries biology of spiny dogfish Squalus acanthias L. Izv. TINRO 10: 105-115 (In Russian).

Ketchen K.S. 1986. The spiny dogfish (Squalus acanthias) in the Notrtheast Pacific and a history of its utilization. Can. Spec. Publ. Fish. Aquat. Sci. 88: 1-78.

King J.R. (ed.). 2005. Report of the study group on fisheries and ecosystem responses to recent regime shifts. PICES Sci. Rep. 28: $1-23$.

King J.R., McFarlane G.A. 2009. Trends in abundance of spiny dogfish in the Strait of Georgia, 1980-2005. In: Gallucci V.F., McFarlane G.A., Bargmann G.G. (eds.), Biology and management of dogfish sharks. Am. Fish. Soc., Bethesda, Maryland, pp. 89-100.

Lindberg G.U., Legeza M.I. 1956. On the two forms of the spiny dogfish, Squalus acanthias. Zool. Zhur. 35: 1685-1688 (In Russian).

Lindberg G.U., Legeza M.I. 1959. Fishes of the Sea of Japan and adjacent parts of the Okhotsk and Yellow Sea. Pt. 1. Opredeliteli po Faune SSSR 68: 1-207 (In Russian).

McFarlane G.A., King J.R. 2003. Migration patterns of spiny dogfish (Squalus acanthias) in the North Pacific Ocean. Fish. Bull. 101: 358-367.

McFarlane G.A., King J.R. 2009. Movement patterns of spiny dogfish within the Strait of Georgia. In: Gallucci V.F., McFarlane G.A., Bargmann G.G. (eds.), Biology and management of dogfish sharks. Am. Fish. Soc., Bethesda, Maryland, pp. 77-87.

McFarlane G.A., King J.R., Beamish R.J. 2000. Have there been recent changes in climate? Ask the fish. Prog. Oceanogr. 47: 147-169.

Mecklenburg C.W., Mecklenburg T.A., Thorsteinson L.K. 2002. Fishes of Alaska. Am. Fish. Soc., Bethesda, Maryland, 1037 p.

Melnikov I.V. 1997. Pelagic predatory fishes - consumers of Pacific salmons: distribution in Russian economic zone and adjacent waters, abundance and some biological features. Izv. TINRO 122: 213-228 (In Russian).

Nagasawa K., Ueno Y., Azuma T., Ogura M., Startsev A.V., Ivanova I.M., Morris J.F.T. 1996. Distribution and biology of epipelagic animals in the northern North Pacific and adjacent seas. - I. Fishes and squids in the southern Okhotsk Sea and western North Pacific off the Kuril Islands in the autumn of 1993. Bull. Natl. Res. Inst. Far Seas Fish. 33: 149-170.

Nakano H., Nagasawa K. 1996. Distribution of pelagic elasmobranchs caught by salmon research gillnets in the North Pacific. Fish. Sci. 62: 860-865.

Nakano H., Semba Y., Kitagawa D. 2009. Fisheries, utilization, and stock status of spiny dogfish in Japan. In: Gallucci V.F., McFarlane G.A., Bargmann G.G. (eds.), Biology and management of dogfish sharks. Am. Fish. Soc., Bethesda, Maryland, pp. 335-341.

Novikov N.P., Sokolovsky A.S., Sokolovskaya T.G., Yakovlev Yu.M. 2002. The fishes of Primorye. Far Eastern State Tech. Fish. Univ. Press, Vladivostok, 549 p. (In Russian).

Orlov A.M., Shevernitsky D.A. 2008. Conservation status of the chondrichthyan fishes of the North-Eastern Atlantic. Byul. Mosk. O-va Ispytatelei Prirody. Otd. Biol. 113: 27-32 (In Russian).

Orlov A.M., Tokranov A.M. 2009. Occurrence of spiny dogfish in the Pacific waters off the northern Kuril Islands and southeastern Kamchatka. In: Gallucci V.F., McFarlane G.A., Bargmann G.G. (eds.), Biology and management of dogfish sharks. Am. Fish. Soc., Bethesda, Maryland, pp. 127-131.
Osipov V.G. 1986. Sharks. In: Vinogradov M.E., Parin N.V., Shuntov V.P. (eds.), Biological resources of the Pacific Ocean. Nauka, Moscow, pp. 94-118 (In Russian).

Palsson W.A. 2009. The status of spiny dogfish in Puget Sound. In: Gallucci V.F., McFarlane G.A., Bargmann G.G. (eds.), Biology and management of dogfish sharks. Am. Fish. Soc., Bethesda, Maryland, pp. 53-65.

Parin N.V. 1968. Ichthyofauna of the oceanic pelagial. Nauka, Moscow, 185 p. (In Russian).

Parin N.V. 2001. An annotated catalog of fishlike vertebrates and fishes of the seas of Russia and adjacent countries. Pt. 1. Order Myxiniformes - Gasterosteiformes. J. Ichthyol. 41(Suppl. 1): 51-131.

Parsons G.R., Hoffmayer E.R. 2005. Seasonal changes in the distribution and relative abundance of the Atlantic sharpnose shark Rhizoprionodon terranovae in the north central Gulf of Mexico. Copeia 4: 914-920.

Schultz L.P. 1936. Keys to the fishes of Washington, Oregon and closely adjoining regions. Univ. Wash. Pubs. Biol. 2: 103-228.

Schwing F.B., Murphree T., deWitt L., Green P.M. 2002. The evolution of oceanic and atmospheric anomalies in the Northeast Pacific during the El Niño and La Niña events of 1995-2000. Prog. Oceanogr. 54: 459-491.

Shuntov V.P., Bocharov L.N. (eds.). 2005. Atlas of quantitative distribution of nekton in the northwestern Pacific Ocean. Vol. 3. Maps. National Fisheries Resources, Moscow, 1080 p. (In Russian).

Shuntov V.P., Bocharov L.N. (eds.). 2006. Atlas of quantitative distribution of nekton in the western Bering Sea. Vol. 4. Maps. National Fisheries Resources, Moscow, 1072 p. (In Russian).

Starks E.C. 1917. The sharks of California. Calif. Fish Game 3 145-153.

Stevens J.D., Wiley P.D. 1986. Biology of two commercially important carcharinid sharks from northern Australia. Aust. J. Mar. Freshw. Res. 37: 671-688.

Taylor I.G, Lippert G.R., Gallucci V.F., Bargmann G.G. 2009. Movement patters of spiny dogfish from historical tagging experiments in Washington State. In: Gallucci V.F., McFarlane G.A., Bargmann G.G. (eds.), Biology and management of dogfish sharks. Am. Fish. Soc., Bethesda, Maryland, pp. 67-76.

Tribuzio C.A. 2004. An investigation of the reproductive physiology of two North Pacific shark species: spiny dogfish (Squalus acanthias) and salmon shark (Lamna ditropis). M.Sc. thesis, Univ. Wash., Seattle, $147 \mathrm{p}$.

Tribuzio C.A., Gallucci V.F., Bargmann G.G. 2009. Reproductive biology and management implications for spiny dogfish in Puget Sound, Washington. In: Gallucci V.F., McFarlane G.A., Bargmann G.G. (eds.), Biology and management of dogfish sharks. Am. Fish. Soc., Bethesda, Maryland, pp. 181-194.

Verissimo A., McDowell J.R., Graves J.E. 2010. Global population structure of the spiny dogfish Squalus acanthias, a temperate shark with an antitropical distribution. Mol. Ecol. 19: 1651-1662.

Walford L.A. 1935. The sharks and rays of California. Calif. Fish Game 45: 1-66.

Ward R.D., Holmes B.H., Zemlak T.S., Smith P.J. 2007. DNA barcoding discriminates spurdogs of the genus Squalus. CSIRO Mar. Atmos. Res. Pap. 14: 117-130.

Wright B.A., Hulbert L. 2000. Shark abundance increases in the Gulf of Alaska. PICES Press 8: 16-17, 22.

Scient. ed.: E. Massutí

Guest ed.: G. Morey.

Received January 18, 2010. Accepted June 15, 2011.

Published online November 22, 2011.

This is a contribution to 13th European Elasmobranch Association Conference (Palma, 19-22 November 2009). 